\title{
ADDITIONS TO THE FLORA OF ARKANSAS
}

\author{
R. DALE THOMAS \\ Department of Biology, Northeast Louisiana University \\ Monroe, LA 71209, U.S.A. \\ EDWIN B. SMITH \\ Department of Biological Sciences, University of Arkansas \\ Fayetteville, AR 72701, U.S.A. \\ ERIC SUNDELL \\ Department of Natural Sciences, University of Arkansas \\ Monticello, AR 71655, U.S.A. \\ PHILIP E. HYATT \\ Department of Biological Sciences, University of Arkansas \\ Fayetteville, AR 72701, U.S.A. \\ CARL AMASON \\ P. O. Box 164, Calion, AR 71724, U.S.A.
}

ABSTRACT

The authors provide a list of 32 additions, significant collections, and reinstatements for the vascular flora of Arkansas, with annotations and citation of voucher specimens.

Since the publication of the second edition of An Atlas and Annotated List of the Vascular Plants of Arkansas (Smith 1988), a number of new records have appeared. Two new endemic species have been described for Arkansas: Polymnia cossatotensis Pittman \& Bates in the Asteraceae (Pittman, Bates \& Kral 1989), and Mespilus canescens J. B. Phipps in the Rosaceae (Phipps 1990). In this paper, we list 32 additional new, significant, or reinstatements of vascular plant records for the Arkansas flora. Several of these records were found by R. Dale Thomas and C. Amason in their southern Arkansas collections, and by P. Hyatt in his floristic study of Baxter County (for his M.S. degree). A number were found by restudy of old material at UARK by E. B. Smith or in collections made by E. Sundell in southeastern Arkansas. A few were collected by other workers. Several were listed as possible additions in Smith (1988).

In the list that follows, taxa are listed alphabetically by family, genus, species and variety; a brief annotation about the collection follows; ranges

SIDA 14(3):483-491. 1991. 
in N. America north of Mexico are taken mostly from Steyermark (1963), Correll \& Johnston (1970), Gleason (1952), Radford et al. (1968), MacRoberts (1988), and Godfrey \& Wooten (1979, 1981); finally, one or more voucher specimens and the herbaria that house the vouchers are cited.

\section{AMARANTHACEAE}

Amaranthus arenicola I. M. Johnst. - This species was reported for Lee Co. by Davis (1974) but voucher material of it could not be located. It is a weed of waste ground from Iowa to Colorado, south to Louisiana, Texas and New Mexico, introduced in Missouri and northeastern states. Authentic material of it was collected on a sandy terrace of the Arkansas River 16 mi NE of Dumas, in Desha Co. in 1988 by E. Sundell (We thank R. L. McGregor, KANU, for verifying the identification); Sundell 8638, with Van Horn, Black \& Etheridge (UAM, UARK).

\section{APIACEAE (Umbelliferae)}

Centella asiatica (L.) Urban - This addition was collected in C. Amason's back yard near Calion, in Union Co. in 1989 by R. D. Thomas and C. Amason; it may have been introduced with plant material from Port Arthur, Texas many years ago, but is spreading aggressively. It is a species of low, wet soils and the U.S. range was earlier listed as Delaware south to Florida and west to eastern Texas; Thomas E Amason 111,290 (NLU, UARK).

Eryngium HoOkeri Walp. - Material of this species was collected at the edge of a backwater pond near the Mississippi River one mi $\mathrm{N}$ of Hwy. 208, in Chicot Co. in 1989 by E. Sundell and D. Etheridge; it was earlier listed for eastern Texas and Louisiana; Sundell E Etheridge 9091, UAM, UARK.

\section{ASTERACEAE (Compositae)}

Conyza bonariensis (L.) Cronq. - Material of this species was collected in a railroad yard in El Dorado, in Union Co. in 1989 by R. D. Thomas and C. Amason; it is a weed of waste places, with a U.S. distribution of Florida to eastern Texas; Thomas $\mathcal{E}$ Amason 112,799 (NLU, UARK).

Marshallia caespitosa Nutt. var. Caespitosa - This variety was collected in 1989 along Pine Creek in Madison Co. by Rory Dalton and Jeanne Dow. We thank L. Watson for verifying the identification. At the time of this collection, it was a new state record. In the meantime, however, Watson and Estes (1990) indicated its range as eastern Texas to ex- 
treme southeastern Kansas, extreme southwestern Missouri, western Arkansas (apparently Montgomery and Yell counties), and eastern Louisiana. The Dalton and Dow collection is the first for the Ozark area of Arkansas; Dalton \& Dow la (UARK).

Solidago drummondi T. \& G. - This species was originally reported for Arkansas by Branner \& Coville (1891), but had been synonymized under $S$. argua var. strigosa (Smith 1988). However, P. Hyatt's collections of it from north-facing limestone bluffs in Baxter Co. (Hyatt 1041.03, UARK) convinced Smith that it should be recognized separately; a 1937 Palmer collection of it from Marion Co. was located at MO, with enquiry to that institution (our thanks to $\mathrm{H}$. H. Schmidt) and Hyatt recently recollected it at Palmer's site (Hyatt 3670.45, MO, UARK). It ranges from Illinois and Missouri to Arkansas and Louisiana.

Solidago ludoviciana (Gray) Small - This species was first listed for Arkansas by Demaree (1943), but was considered a synonym of $S$. salicina by Smith (1988), a synonym of $S$. arguta by MacRoberts (1988), and a synonym of $S$. bootii ( $S$. arguta var. bootii) by Correll \& Johnston (1970). It evidently should be recognized as a separate species. It is now known in Arkansas from Calhoun (Miller 628, UARK), Cleveland (Miller 316, UARK), Columbia (Miller 267, UARK), Hempstead (Moore 400449, UARK), Miller (Roberts 914 \& 940, UARK), Nevada (Roberts 119 \& 487, UARK), and Union (Thomas 102,729, NLU, UARK) counties, grows in moist sandy soil, and ranges on into Texas and northern Louisiana.

Soliva mutisir Kunth in H.B.K. - Restudy by Smith of a specimen collected several years ago as a garden weed in Pine Bluff, by Marie P. Locke in Jefferson Co. indicated that it was material of this species; it is a weed of disturbed areas, previously known from the U.S. in eastern Texas and Louisiana; Locke 3084 (UARK).

\section{BORAGINACEAE}

Myosotis discolor Pers. - A previously misidentified 1980 collection from Benton Co. by Ellen Neaville, on recent study was found by Smith to be material of this species. A population of this species was reported by Gary Tucker (pers. comm.) from Pope Co. (Holben 34159, and Sanders 65, both at APCR); it has not persisted there. It was recently found as a ball field weed in Monticello in Drew Co. by E. Sundell. This plant is adventive from Europe and Western Asia and occurs in waste areas on both coasts of N. America (M. versicolor in Gleason 1952) and, now, sporadically in Arkansas and Louisiana; Neaville 5 (UARK), Sundell 9403 (NLU, UAM, UARK). 


\section{CAMPANULACEAE}

Wahlenbergia marginata (Thunb.) DC. - This new record was collected on a sandy road bank $2.1 \mathrm{mi}$ south of Calion, in Union Co. in 1989 by R. D. Thomas and C. Amason; it ranges from the Carolinas south to Florida and west to Louisiana and Arkansas. Thomas \& Amason 111,677 (NLU, UARK).

\section{CAPPARACEAE}

Cleome gynandra L. - Material of this species, collected as a weed in a soybean field in Prairie Co., was sent to UARK by John Boyd (Coop. Ext. Service, Little Rock) for identification, and was determined by E. B. Smith; it was listed for Arkansas by Branner \& Coville (1891), but on the basis of no voucher material available was excluded from the Arkansas flora by Smith (1988). It should be reinstated; it is a weed of African origin, in much of the U.S. from North Carolina to eastern Texas; Boyd s.n., 3 Aug 1989 (UARK).

\section{CARYOPHYLLACEAE}

Stellaria pallidd (Dumort) Pire - This close relative of $S$. media was collected by P. Hyatt in Baxter Co. in 1988 and identified by R. K. Rabeler (Michigan State Univ.). It has petals minute or absent and 2 stamens with gray-violet anthers; $S$. media has well-developed petals (rarely absent) and 3 - 7 stamens with red-violet anthers. This Eurasian weed was reported for North Carolina, Pennsylvania, and Michigan in Rabeler (1988). It has since been collected (mostly by Hyatt) in Arkansas from several counties and is evidently common here. Presently, $S$. pallida is known from Ashley, Baxter, Boone, Carroll, Conway, Crawford, Independence, Izard, and Washington counties. It occurs at least at scattered locations in the eastern U.S. Much of the UARK material is out on loan, so we cite only the following vouchers: Baxter (Hyatt 1077.03, UARK), Boone (Hyatt 1185.05, UARK, Independence (Hyatt 1510.32, UARK), and Izard (Hyatt 1208.33, UARK) counties.

\section{CONVOLVULACEAE}

Cuscuta coryli Engelm. - This species was listed for Arkansas by Branner \& Coville (1891), but on the basis of no known voucher material was reduced to a possible addition by Smith (1988); recently collected material of it growing on Campsis radicans near Lake Wedington in Washington Co. was determined by L. A. Prather (Okla. State Univ.); its range is southern New England to Montana, south to North Carolina, Arkansas, Texas, New Mexico, and Arizona. Cartwrights.n., 17 Aug 1988 (UARK). 
Cuscuta obtusiflora H.B.K. var. glandulosa Engelm. - This species was collected in Union Co. in 1989 by E. Sundell, R. D. Thomas and C. Amason; it ranges in the U.S. through the gulf states, including Texas and Arkansas. Sundell, Thomas E Amason 9176 (UAM).

\section{CYPERACEAE}

Bulbostylis ciliatifolia (Ell.) Fern. - Earlier reports of this species for Arkansas (Moore 1965, Wilcox 1973) were probably based on material of the very similar B. capillaris. Smith (1988) excluded it, but it should be reinstated. Authentic material of it is now known from Miller (Roberts 902, UARK), Nevada (Roberts 134, UARK), Ouachita (Thomas et al. 100,682, NLU, UARK), and Union (Thomas et al. 112,946, NLU, UARK) counties.

Carex hirtifolia Mack. - This new record extends the southern range of the species about $80 \mathrm{mi}$ southwest from the nearest known location in southeast Missouri (previous range: New Brunswick and Quebec to Ontario and south to Maryland, Kentucky, Missouri and Kansas); it was collected in sandy soil over sandstone outcrops in Baxter Co. by P. Hyatt; Hyatt 2823.03 (UARK).

Cyperus hystricinus Fern. - Some of the material at UARK collected on sand hills of southwest Arkansas, earlier determined $C$. retroflexus Buckley, was determined in 1990 by R. Carter (Valdosta State College, Ga.) as this new record; this species is now known in Arkansas from Miller (Roberts 920A, 944, UARK) and Union (Thomas \& Amason 111,726, NLU, UARK) counties. Its range is difficult to determine, since it has been confused with $C$. retroflexus, but apparently includes much of the eastern U.S.

Eleocharis flavescens (Poir.) Urban (including E. olivacea Torr.) - This species was listed for Arkansas by Branner \& Coville (1891), but on the basis of no known voucher material was not included by Smith (1988); material of it was collected partly submerged in a stream five mi south of Calion in Union Co. in 1988 by E. Sundell, with R. D. Thomas, C. Amason, and D. Etheridge; its range is eastern N. America, west to Minnesota and Texas. Sundell 8754 (UAM, UARK).

Fuirena simplex Vahl var. aristulata (Torr.) Kral - A specimen from Little River Co. was determined this by R. Kral (Vanderbilt Univ.) although it was apparently mapped (Kral 1978) as var. simplex; both the Little River (Iltis 5170A, UARK) and the Miller (Atkinson s.n., 15 Jul 1946, UARK) Co. dots for $F$. simplex in Smith (1988) represent material of this variety. In addition, two recent collections of the variety (Sadler 448, 463) have been made in Crawford Co.; it is a plant of open, limy or sandy 
soils, ranging in the U.S. from Nebraska and northwestern Missouri to Texas and New Mexico (Kral 1978).

\section{FABACEAE (Leguminosae)}

Crotalaria angulata Miller - Material of this species at UARK has passed as C. sagittalis; it is now known from Bradley (Leslie E Cornish 1028, NLU, UARK), Clark (Tucker 12337, APCR, UARK), Ouachita (Roberts 305A, UARK), and Prairie (Smith 4132, UARK) counties. It is found from Virginia, south to Florida, west to Alabama and Arkansas.

Desmodium cuspidatum (Muhl. ex Willd.) DC. var. Longifolium (T. \& G.) Schub. - Material of this variety was not recognized in UARK material earlier (Smith 1988); Smith now recognizes it for Baxter (Hyatt 2327.03, UARK) and Pulaski (Merill 985, UARK) counties. It ranges from the north central U.S. south to Alabama, Louisiana and Kansas.

\section{GERANIACEAE}

Geranium texanum (Trel.) Heller - An old specimen of this species, misidentified as $G$. carolinianum, has been found from Miller Co. at UARK; it might be better treated as G. carolinianum L. var. texanum Trel. and occurs in Arkansas, Louisiana and Texas; Moore 510141 (UARK).

\section{HYPERICACEAE}

Hypericum denticulatum Walt. - This addition was collected in Ashley Co. in 1988 by E. Sundell and D. Etheridge; its range extends from New Jersey to Ohio and southern Illinois, south to northern Florida, southeastern Arkansas and Mississippi; Sundell E Etheridge 8531 (UAM).

\section{IRIDACEAE}

Iris hexagona Walt. - This Iris was recently collected along a Forest Service road near Chapel Hill in Sevier Co. by A. J. Higginbottom (P. O. Box 102, Kirby, AR) and determined by Smith; the range extends from South Carolina to Florida, west to southeastern Texas and north to Arkansas and southeastern Missouri; Higginbottom s.n., 30 Apr 1990 (UARK).

\section{LAMIACEAE (Labiatae)}

Mentha arvensis L. - This mint was collected in Baxter Co. in 1989 by P. Hyatt. Its site of collection (below Bull Shoals Dam) puts the small population in jeopardy, with high water releases from the dam; elsewhere it occurs from Canada through much of the northern half of the U.S., to New Mexico and Arizona; Hyatt 2245.03 (UARK). 


\section{LILIACEAE}

Smilax ecirrhata (Engelm.) Wats. - Two old collections at UARK from rich woods in Conway (Moore 1242, UARK) and Newton (Moore $\mathcal{E}$ Iltis 492, UARK) counties represent this species. The plant occurs from Ontario to Minnesota and South Dakota, south to Tennessee and Arkansas.

\section{MALVACEAE}

Hibiscus coccineus Walt. - This species is cultivated in our area, and is locally escaping to disturbed areas in and around El Dorado in Union Co.; it ranges from Georgia to Florida and Alabama west to Arkansas and Louisiana; Sadler 439 (UARK).

\section{NYCTAGINACEAE}

Mirabilis Jalapa L. - This cultivated species, native to tropical America, was collected as an escape in Union Co. in 1989 by R. D. Thomas and C. Amason. It had earlier been reported for Arkansas by Thompson (1977) and by Leslie (1986), probably on the basis of cultivated material. It was excluded by Smith (1988), but should be reinstated; Thomas E Amason 111,373 (NLU, UARK).

\section{POACEAE (Gramineae)}

Hydrochloa Caroliniensis Beauv. Luziola fluitans (Michx.) Terrell \& H. Robins. - This species has been found in Hot Springs Co. as a serious weed in a fish pond near Malvern. Material of it was sent to UARK by W. D. Sample (Fish \& Game Serv., Stuttgart) for identification and was determined by Smith (Sample s.n., 28 Jul 1989, UARK). It may become a serious pest in fish ponds of southern Arkansas. It ranges in the U.S. from North Carolina to Florida, west to Arkansas and eastern Texas; it has also recently been collected in Cleburne Co. (Thomas et al. 122,059, NLU, UARK), and Union Co. (Sundell et al. 8251, UAM; Thomas 104,756, NLU).

\section{ROSACEAE}

Prunus caroliniana Ait. - This cultivated species has been collected in several Arkansas counties, apparently always in cultivation, and was listed by Tucker (1976) as persistent after cultivation. However, a collection in Union Co. in 1989 by R. D. Thomas and C. Amason was apparently from an escaped plant. It was excluded by Smith (1988), but should be reinstated; it ranges from South Carolina, along the coast to Texas and Arkansas; Thomas \& Amason 111,245 (NLU, UARK). 


\section{SAXIFRAGACEAE}

Decumaria barbara L. - This species was collected along a roadside in southern Union Co. in 1989 by R. D. Thomas and C. Slaughter; the species occurs in southeastern Virginia, south to Florida and west to Louisiana, Arkansas and Tennessee; Thomas E Slaughter 110,064 (NLU, UARK).

\section{SCROPHULARIACEAE}

Agalinis homalantha Pennell - Some material from near the Arkansas River in Pine Bluff, Jefferson Co., collected several years ago by Marie P. Locke, on further study by Smith is apparently this species. It was reported for Bradley Co. by Leslie (1976), on the basis of material of $A$. tenuifolia, and was therefore excluded by Smith (1988) but should be reinstated. It occurs in eastern and north central Texas to southern Oklahoma and southern Arkansas; Locke 53 \& 858 (UARK).

\section{REFERENCES}

BRANNER, J. C. and F. V. COVILLE. 1891. A list of the plants of Arkansas. Annual Report for 1888. Ark. Geolog. Survey 4:155-242.

CORRELL, D. S. and M. C. JOHNSTON. 1970. Manual of the vascular plants of Texas. Texas Research Foundation, Renner, Texas.

DAVIS, J. R. 1974. Vascular plants of Lee County, Arkansas. M.S. Thesis, Ark. State University, State University, AR.

DEMAREE, D. 1943. A catalogue of the vascular plants of Arkansas. Taxodium 1:1-88.

GLEASON, H. A. 1952. The new Britton and Brown illustrated flora of the northeastern United States and adjacent Canada. New York Botanical Garden, Bronx, N.Y.

GODFREY, R. K. and J. W. WOOTEN. 1979, 1981. Aquatic and wetland plants of the southeastern United States. Monocotyledons (1979), Dicotyledons (1981). The Univ. of Georgia Press, Athens, GA.

KRAL, R. 1978. A synopsis of Fuirena (Cyperaceae) for the Americas north of South America. Sida 7:309-354.

LESLIE, S. A. 1986. A preliminary survey of the vascular flora of Bradley County, Arkansas. M.S. Thesis, Northeast Louisiana Univ., Monroe, LA.

MACROBERTS, D. T. 1988. A documented checklist and atlas of the vascular flora of Louisiana. Pts. I, II, \& III. Louisiana State Univ., Shreveport, LA.

MOORE, J. E. 1965. A study of the vegetation of Petit Jean Mountain in central Arkansas. Castanea 30:1-37.

PHIPPS, J. B. 1990. Mespilus canescens, a new rosaceous endemic from Arkansas. Syst. Bot. $15: 26-32$.

PITTMAN, A. B., V. BATES, and R. KRAL. 1989. A new species of Polymnia (Compositae: Heliantheae) from the Ouachita Mountain region of Arkansas. Sida $13: 481-486$.

RABELER, R. K. 1988. Eurasian introductions to the Michigan flora. IV. Two additional species of Caryophyllaceae in Michigan. The Michigan Botanist 27:85-88. 
RADFORD, A. E., H. E. AHLES and C. R. BELL. 1968. Manual of the vascular flora of the Carolinas. The Univ. of North Carolina Press, Chapel Hill, N.C.

SMITH, E. B. 1988. An atlas and annotated list of the vascular plants of Arkansas. 2nd ed. Kinko's, 653 West Dickson, Fayetteville, AR 72701.

STEYERMARK, J. A. 1963. Flora of Missouri. Iowa State Univ. Press, Ames, IA.

THOMPSON, R. L. 1977. The vascular flora of Lost Valley, Newton County, Arkansas. Castanea 42:61-94.

TUCKER, G. E. 1976. A guide to the woody flora of Arkansas. Ph.D. Diss., Univ. of Arkansas, Fayetteville, AR.

WATSON, L. E. and J. R. ESTES. 1990. Biosystematic and phenetic analysis of Marshallia (Asteraceae). Systematic Botany 15:403-414.

WILCOX, W. H. 1973. A survey of the vascular flora of Crittenden County, Arkansas.

Castanea 38:286-297. 


\section{$2 \mathrm{BHL}$ Biodiversity Heritage Library}

Thomas, R. Dale et al. 1991. "ADDITIONS TO THE FLORA OF ARKANSAS." SIDA, contributions to botany 14, 483-491.

View This Item Online: https://www.biodiversitylibrary.org/item/34596

Permalink: https://www.biodiversitylibrary.org/partpdf/162669

\section{Holding Institution}

Missouri Botanical Garden, Peter H. Raven Library

\section{Sponsored by}

Missouri Botanical Garden

\section{Copyright \& Reuse}

Copyright Status: In copyright. Digitized with the permission of the rights holder.

License: http://creativecommons.org/licenses/by-nc-sa/3.0/

Rights: https://biodiversitylibrary.org/permissions

This document was created from content at the Biodiversity Heritage Library, the world's largest open access digital library for biodiversity literature and archives. Visit BHL at https://www.biodiversitylibrary.org. 